\title{
The Impact Of Selling Style And Sales Performance On The Manufacturing Firm
}

\author{
Isiuwa, C. John ${ }^{1 *}$ Dauda Tijjani ${ }^{2 *}$ \\ 1. Faculty of Humanity, University of Port Harcourt, Choba, Portharcourt, Rivers State, Nigeria. \\ 2. Faculty of Management science, University of Port Harcourt, Choba, Portharcourt, Rivers State, Nigeria.
}

\begin{abstract}
This study seek to appraise the impact of Selling style and sales performance in the Manufacturing firm with special reference to First Aluminum Company Limited. The researcher reviewed some related of manufacturing firm roles of the sales forces, managing the sales forces, selling style and sales performance processes. In chapter one the researcher deal with the introduction, background of the study, the statement of the problems, objective of the study, research questions, significance of the study, scope of the study, limitations of the study and definition of terms. The chapter two, contains the literatures review, and others function of the topic. Chapter three deals with the research methodology, research design, sources/methods of data collection, sample technique, validity and reliability of measuring instrument, and method of data analysis. Chapter four presentation and analysis of data, and interpretation of results. While the last chapter, chapter five deals with the summary and finding, conclusion and recommendations of the research project.
\end{abstract}

\subsection{Background Of The Study}

\section{Introduction}

This research work deals with the impact of selling style and sales performance in the manufacturing firm , this industrial firms and institution that has recognized the usefulness of promotion do not see selling style and sales performance as equal to or surpassing the other element of promotion mix like advertising, publicity, and sales promotion end up spending more money in those other promotion without achieving corporate objective.

Selling style and sales performance unlike other promotional tools communicates information about company's product to the prospects on an inter - personal basis. The communications information about company's product to the prospects by other promo tools are done on impersonal basis (Nebo Okwudili G, 2006:9).

In industrial marketing there is no other promo tool that brings the firm and prospective buyers into direct content. The only promo tool that makes this possible is personal selling. Selling style and sales performance therefore is of greater significance for marketers of industrial goods than that for consumer goods.

It is another promo-tools used for the achievement of marketing of marketing attention and spontaneous purchases. Obiesike (2003:151) defined selling style and sales performance as oral presentation in a conversation with one or more prospect purchase for the purpose of marketing sale it can be seen as face to face interaction between two or more people the seller and the buyer with the aim of closing the sales through selling style and sales performance the awareness of the product can be created interest around product preferences developed price negotiated and finally, sales closed, it should be understood that while advertising is a monologue selling style and sales performance is a dialogue between the seller or his representative and others some of his various types of selling job includes responsive trade selling missionary selling techniques and creative selling.

A sales man informs the customer about the new product introduced in a market. A sales man makes search for new customer and convince them to buy and use the product. The selling style and sales performance or salesmanship has made large scale production and sales possible selling style and sales performance has great application to the marketing of industrial goods and services because condition in the industrial market can be managed well by sales men.

Manufacturing firm are those product bought or purchased for further processing or for use in conducing a business. Thus, the detention in conducting a business. Thus, the detention between a consumer product and an manufacturing firm is based on the purpose for which product is brought, industrial users make use specifications negotiation value and vendor analysis and whenever they buy industrial items for sue in further production or operations or for resale to and users whereas the consumer buy on the basis of description style and colour and for household use only. 
As regards to the nature of the market the industrial user buy in bulk and are geographic concentrated the industrial market have more informed buyers they engaged highly knowledgeable persons to buy for them most often the buyers have both technical and commercial knowledge of the product the demand for industrial material is derived demand because purchased are made on the basis of anticipated demand for final product for which it is being used to produced their buying decision are characterized here are jointly made there is need for closer or direct relationship between the buyer and the producer because of the after sales services that may be needed. However, some product can service the dual purpose of both industrial and consumer goods e.g0 automobile, drugs, building material etc.

Consumer products are those goods and services used by the ultimate consumer for satisfying his personal and non - business needs such product could be tangible or intangible, durable or non - durable agricultural or manufacturers bought for personal for resale or facilitating manufacturing and distribution processes of yet another product.

As regard to the nature of the demand the consumer product is primary demand since the products are purchased to satisfy primary human needs and are widely dispersed and require mass marketing there exist large number of relatively small transactions in the consumer market many buyers and sellers are involved in the consumer market. The consumer market has long and multiple channels of distribution to be able to reach the large dispersed market.

The industrial buying process starts with the user department who discovers anticipates a problem in its operation that it believes can overcome with the addition of a certain product or service the head of the user department draw up a requisition describing the desired specifications she feels the product services must have to solve her problem, the requisition form is then sent to the purchasing department by the user department based on the specification required the purchasing department then conducts a search for qualified sources of supply when source of supply are identified based on specifications the purchasing department calls for quotation which when received they are analyzed on the basis of price delivery services etc. the prospective suppliers quotation are then compared with cost of producing the product in house in a make or buy decision if it is decided that the buying firm can produce the product more economically the buying process for the product in question is discontinued other wise, the process continues a supplier or source of supply is selected from those who have submitted their quotations. The purchasing department places order for the product and copies of the purchase order are sent to the user department of accounting/ finance and any other concerned department within the organization. After the product is shipped received and used a fellow up activity with the user department is necessary to determine the level of satisfaction or dissatisfaction of the user with the product.

The buying process of industrial marketing manager is that it shows how customer make purchases decision and also shows what must be done in the company product or service is to be consider and ultimately purchased the purchase of manufacturing firm are usually based in rational motive, which means that the marketing appeals should be on the rational motive. Manufacturing firm s can be acquired by out right purchase or leasing, packing of manufacturing firm are more of protective than promotional in nature.

There is heavy emphasis on selling style and sales performance and trade shows for manufacturing firm more managers has come to realize the impact of selling style and sales performance there has been a growing awareness of the increasing importance of the selling style and sales performance as the key link in the process of selling more and more companies are spending bigger amount on the selection and training of their sales person.

They consider this to be prime important companies which train their salesperson thoroughly find high rate of wastage of this sales person to other companies anxious to benefits from the employment of well trained capable sales person (Okorie Festus E, 2004:8) Selling style and sales performance is used to satisfy marketing objectives like satisfaction of customers want by identifying their problems and trying to satisfy need and want.

The study covers the factors that may account for the impact iveness of selling style and sales performance of the selected industrial company and manufacturing firm users. In the manufacturing firm and service there is so much emphasis on selling style and sales performance because the products are often complex and expensive buyers and buying influence require and demand very technical on the spot answers to complex question before they will purchase, post and pre - sale services and technical assistance are common requirement which only selling style and sales performance can provide however, for direct or selling style and sales performance to succeed the firm has to sale it potentially competent sales forces, with the right qualities train and develop them organize and motivate them adequately to achieve the marketing objective of the company.

\section{First Aluminum Company Plc Commenced}

First aluminum company plc is located at Transamadi Industry Layout Port Harcourt with branches in Lagos the company sales specializes in the production of silver and bronze profit for the fabrication of door and windows. 
The company has about five expatriate technical management staff from India including some indigenous manager who involved in the management team.

\subsection{STATEMENT OF THE PROBLEM.}

- $\quad$ Based on past experience, it has been observed that poor selection of sales people have contributed to the poor performance personal selling,

- Poor motivation of sales people has been of immense draw back to impact personal selling,

- Poor sales presentation techniques is also a factor, unpleasant attitude of consumer toward personal selling

\subsection{OBJECTIVES OF THE STUDY}

To ascertain how impact management of selling style and sales performance can be use to achieve volume of sales in the First Aluminum company Plc,

To appraise the sales forces management strategies of First Aluminum company plc,

To ascertain if there are defects or otherwise in the current selling style and sales performance management Aluminum company plc,

To identify the problems militating against impact management of sales forces in first Aluminum company plc,

\subsection{RESEARCH QUESTIONS.}

How can First Aluminum Company carry out their personal management or services?

Are there defects in the current sales force management programme of first Aluminum company extrusion plc? What is the relationship between impact management of sales force and increased sales volume?

What are the problem militating against impact sales force management in Aluminum company?

How can First Aluminum extrusion use selling style and sales performance to achieve increased sales volumes? How can impact management of sales force be used to achieve high sales volume?

\subsection{SIGNIFICANCE OF THE STUDY.}

This research work is significant and beneficial to

1. Industrial firm that are yet to discover the benefit of personal selling.

2. Any researcher wishing to discover the rational for adoption of selling style and sales performance by industrial firms.

This study will also clarify and inform the yet to embrace selling style and sales performance like manufacturing as the need to accept it as one of the strongest weapon of the promotional tool.

The study through it finding and recommendation will enable the case study company to solve its problem of using selling style and sales performance as promotional tool when it is awkward to do so, and when it is suitable to do as well.

Although the target market of manufacturing firm are fewer the study will help and interest manufacturers of manufacturing firm to know how best to adopt selling style and sales performance as promotional tool for reducing customers perceived risk on product. It still seems to be neglected in the field of marketing programmes. It has been remarkable, how relatively little attention personal in the industrial marketing has received in the professional intercourse and in academic research.

However, existing knowledge is limited concerning how impact selling style and sales performance is used in the manufacturing firm s.

This research work is focused on the manufacturing firm by industrial selling by first aluminum extrusion company plc and the industrial customers and prospective. The company's products are brought by organization for the purpose of producing other goods for resale.

\subsection{Scope Of The Study.}

Since the study is concerned with the impact of selling style and sales performance in the manufacturing firm s, the researcher shall limit the study to First Aluminum Company Plc Port-Harcourt and other aluminum company in Port Harcourt and Aba. The study will also investigate and benefits the selling style and sales performance to the industrial producer and industrial user.

\subsection{Limitation Of The Study.}

This research work is limited to an extent due to some limiting factors that stand as constraints in cause of the research work.

The minor factor involves the inability of the respondent to respond accurately to the researchers questionnaires. The management was affair to disclosing some of their market trends and other relevant 
information concerning their business opportunities financial materials with the polytechnic library created some to the researcher the constraint not with standing the researcher strived to accomplish this project work.

\subsection{Definition Of Terms.}

MANUFACTURING FIRM : Manufacturing firm $\mathrm{s}$ are those product brought by individuals and organization for further processing or for use in conducing a business (Egu Anthony O. \& Co, 2008:12)

PERSONAL SELLING: A selling style and sales performance is that aspect of the total promo tool which makes possible the occurrences of direct personal communication between the organization and its prospective buyer for the purpose of facilitating exchange (Nebo Okwudili G, 2004:350)

WHOLESALERS: These are marketing firms that are engaged in selling goods and services to those procuring them for the purpose of reselling or business use. This business activity of wholesalers is called wholesaling. To operate this kind of business requires high level of capital outlet. The reason for this being that most wholesalers finance the business of producers whom they buy from any many a time maintain their own warehouse or hire many storage facilities amounting to several millions of naira.

SALESMAN AND SALESFORCE: a salesman is one who has been employed to help a given firm to achieve its organizational objectives especially as it relates to selling its product and creative positive image about the company at large. Sales force therefore represents group of salesmen that perform the function of a salesman. When salespeople are employed it becomes when salespeople to coordinating their activity in order to achieve harmony and avoid each working at cross purposes with other parties.

USER: The person who consumes or uses the product purchased is described is called the users. His role is unquestionable because without him, the product will not be procured in the first place. The purpose to which the product will be put will determine the type of product to be acquired and even the time needed.

\section{References}

[1] Nebo Okwudili G. (2006) Sales management strategic, Approach Owerri Ujoma Printing press Co

[2] Okorie Awa H (2002) Strategic Marketing Promotion Mix, Enugu ceekery business center

[3] Egu Anthony O. (2008) Industrial Marketing in Nigeria Aba Brighton Graphics

[4] Okorie Fetus E. (2004) Leeway to Skillful selling Owerri Tonyben

[5] Nebo Okwudili G. (2004) Marketing contemporary and Comprehensive approach Owerri Rock business center

\subsection{INTRODUCTION.}

\section{Related Literature}

\subsection{DEFINITION OF PERSONAL SELLING.}

The act of personal has shown a very drastic growth in the modern business activities owing to complex business environment relating to competition civilization and other development.

Selling style and sales performance is a unique promotional tool not only because it has the onerous task of ultimately converting the outputs of the organization to catch, but also because it is the only major tool that communicates persuasively using inter- personal relationship. (Awa 2000, 196)

Selling style and sales performance involved trained sales staff calling on target customer to make presentation and of course promotion aimed at building favourable attitude towards a product or services.

The selling style and sales performance activities of the industrial firms required a technical trained staff that can tailor their attitudes and behaviour to suit and satisfy the demand of the target audience and also train staff that examine the personal policies the methods and organization of his competitors (Festus E. Okorie, 2004:53)

Most often manufacturing firm is bulky and cannot be moved easily by the sales staff. Therefore the use of other techniques to present the manufacturing firm to the prospective buyer is necessary, catalogues can be used to solve the problem, but whatever may be the case, selling style and sales performance in the industrial sector, for industrial capital goods is not easy task. This may be the reason why some firms has it as their least choices in their choice of promotional tool.

\subsection{CONDITIONS FOR THE USE OR SELLING STYLE AND SALES PERFORMANCE FOR MANUFACTURING FIRM}

As have been said, selling style and sales performance is a promo tool used for achieving marketing attention and spontaneous purchase OBIESIE AND ONUOHA (2005) defined selling style and sales performance as oral presentation in conversation with one or more prospective for the purpose of making sales.

It can be seen as face - to - face interaction between two or more people, the seller and the buyer with the aim of closing the sales selling style and sales performance is a dialogue between the seller and others which the seller must tailor his speech and behaviour to appeal to the purchase in order to induce him/her to buy.

Selling style and sales performance as a promotional strategy. 
Technical product: when the product concerned is a highly technical and sophisticated type, the sue of selling style and sales performance is very vital for explanation of the features and other complex information about the item,

Frequent Purchased: Capital intensive product if the product is the type that is regularly purchased with huge sum of money involved the firm can make use of selling style and sales performance since the money derivable from the activity is enough,

Concentrated buyers: where the market is concentrated with a geographical location persons selling is often the best option, to avoid wastage of effort emanating from exposing the advert to those who are not the market for the product.

Small organization: when the firm is very small with a huge income, it can go for selling style and sales performance instead of advertising which is more expensive, the condition for this is that the firm has small market that the sales force can cover with minimum marketing efforts (Onuoha \& Amaechi, 2005:130).

\section{ARGUMENT FOR THE USE OF SELLING STYLE AND SALES PERFORMANCE}

According to Onuoha J. K. \& Amaechi (2005:132), benefits derivable from selling style and sales performance includes;

1. It can be used to achieve immediate sales.

2. There is easy adjustment of marketing techniques by the salesman to suit the prospect.

3 Wastage of effort eliminated as the sales force meets the real buyer of the project.

4. It provides opportunity for studying the market against research purpose while creating the avenue for after sales services to the customers.

5. Test - marketing of new products successfully to be carried out through the application of selling style and sales performance processes.

\section{ARGUMENT AGAINST PERSONAL SELLING}

It is an expensive way of promoting a product especially when the customers are geographically.

High level of human bias could make the buyer to close his interest in producing this item when he suspects the salesman to be a swindler.

When a 'uniformed general' is employed to handle the job, it could lead to total number of market situation as it will be unable to persuade the people to adopt the product.

\subsection{APPROACH FOR THE USE OF SELLING STYLE AND SALES PERFORMANCE IN MANUFACTURING FIRM .}

Manufacturing firm through selling style and sales performance is a task many firms have backed out at in our economy (developing) this is because the majority of the population is living below the poverty line. In promoting manufacturing firm short term inducement of values is offered to stimulate interest in buying a product or services in other to actualize the objectives of sales promotion and personal selling. The sales force must be trained to know the product they promote.

They must be ready to provide customers services in other to win customers patronage. Impact use of catalogue may be used to deficit the product because the product of such an awkward to carry out.

\subsection{THE ROLE OF THE SALES FORCE}

Selling style and sales performance is the inter-personal arm of promotion mix. Advertising consist of one way, selling style and sales performance involves two way personal communication between sales person and individual customers whether face to face, by telephone, through video, conference, or by the other means. Selling style and sales performance can probe customers to learn more about the problem.

Selling style and sales performance can be more impact than advertising in more complex selling situation. They can adjust the marketing often to fit the special need of each customers and can negotiate terms of sales.

They can build longer term personal relationship with their decision making. The role of selling style and sales performance varies from company to company. Some firms has no sales people at all. For example company that sells only through manufacturer, representatives, sales agent or brokers. In most firms however the sales force plays a major role. In companies that sells business product, such as Xerox, the company sales people work directly with the customers. The sales force serves as a critical link between a company and it customers.

In many cases, sales people serve masters, both the seller and buyer. Firstly they present the company to customers. They find and develop new customers and communication information about the company product 
and services. They sell product by approaching customers, presenting their product, answering objections, negotiating price and terms and closing sales.

\subsection{MANAGING THE SALE FORCE.}

Sales force management can be define as impact and efficient use of selling style and sales performance effort through planning, organizing staffing directing, motivating, evaluating and controlling for the purpose of achieving organizational sales objectives (Nebo Okwudili G, 2006:22).

It includes designing salesforce strategy structure, recruiting and selecting salesforce, training salesforce compensating salesforce and supervisory and evaluating the firms salesforce.

The channel of distribution in industrial market is usually short and is generally directed from the manufacturers to the users industrial demand is also derived demand, the purchase is dependent upon what happens in the end market for instance the amount still coils one buy is largely determined by the market demand for rooting sheets by the customers.

Another characteristics of industrial selling are reciprocity occasionally reciprocity is practice in buying from one particular company because it buys from you. If the product is comparable or better than comparable or better than competitors product in terms of equality, services and prices such as practice pose not problem. As a matter of fact under such circumstances, it is the logical ethical and sensible thing to do however, problem occur when there is pressure to buy an inferior product reciprocally.

the analysis, planning, implementation and control, of sales force activities (Kotler 2001:583) it include designing, sales force strategy and structure, recruiting, selecting, training, compensating, supervising and evaluating the firms.

\section{MAJOR STEPS IN SALE FORCE MANAGEMENT.}

Recruiting / selecting sales force

Training sales people

Compensating sales force

Supervising sales people

Designing sales force strategy and structure

\section{DESIGNING SALES FORCE STRATEGIES \& STRUCTURE}

Marketing manager faced with several sales force strategy and design questions. How should sales people and their task be structure?

How big should sales people sell alone or work in terms with other people in the company. Should they sell in the field or by telephone?

Territorial sales force structure for each sales person is assigned to an exclusive geographical area, and sell in company full line of product or service to all customers in first territory.

The organization has many advantages it clearly defines the sales person job, and because only one sales person works in the territory, he/she gets all the credit or blame for territory sales. The territorial structure also increase the sales person desire to brutal local business relationship that in turn improves selling style and sales performance impact iveness, product sales force structure.

Sales people must know their product especially when the products are numerous and complex. These need together with the growth of product management, customers sales a force structure in which they organize the sales force alone. Customers or industry line or separate industry line or separate industry for serving current customers versus findings new ones and for major account versus regular account tele-marketing.

\section{OUTSIDE AND INSIDE SALES FORCE}

A company may have an outside sales force (or field sales force) an inside sales force, or both outside sales people travel to call on customers.

Inside sales people conduct business from their office via telephone or visits from prospective buyer.

To reduce time demand on their outside sales force, many companies have increase the size of their inside sales force. Inside sales people include technical support people sales assistance and the tele- markets, technical supports people who provide technical information and answer the customer's question. Sales assistance provides clerical back up for outside sales people.

They call a lead and confirm appointment conduct credit check, fellow up on deliveries and answers customers question when outside sales people cannot reached tele market use the phone to find new lead and quality prospect for field sales force, or to sales and services account directly. 


\section{RECRUITING AND SELECTING SALES FORCE}

At the heart of any successful sales operation there is always a sales man sales person selection can greatly increase performance. Beyond the difference in sales performance, poor selection result in costly turnover when a sale person quite, the cost of the findings and training new sales can run into millions of naira.

\section{A GOOD SALES PERSON}

One survey suggests that good sales people have a lot of enthusiasm persistence, limitative self confidence and good commitment. They are committed to sales as a ways of life and have a strong customer's orientation. Another study suggests that goods sales people are independent and self motivated and are excellent listener.

Still another advised that sales people should be mend to the customers as well persistence, enthusiastic and attentive and above all honest. They must be internally able to build strong relationship with customers.

Finally study shows that good sales people are term player rather the loners.

\section{TRAINING SALES PEOPLE}

Training can be expensive it can also yield dynamic return on the training investment. Training programs have several goal / sales people need to know and identify with the company so, most training program begin describing the company history and objectives, its organization, its financial structure and facilities and its client product and market.

Sales people also need to know the company product so sales trainee are shown how product are produced and their work. They also need to know the customers and competitor characteristics, so the training programme researcher them about competitors characteristics and strategies and about different types of customer and their need, buying motives and buying habits, because sales people must know how to make impact presentation, they are trained in the principle of selling.

Finally sales people need to understand field procedures and responsibilities.

\section{COMPENSATE OF SALES PEOPLE.}

To attract sales people a company must have a appealing compensate plans.

There plans vary greatly both by industry and by companies within the same industry the level of compensation must be closed to the "going rate" for the type of sales job and indirect skills.

To pay less than the going rate will attract too few quality sales people to pay more would be unnecessary.

Compensation is made up of several element fixed amount a variable amount expensive and fringe benefit. The fixed amounts usually a salary give the sales person some stable income. The variable amount which might be performance rewards of the sales man greater effort, expenses allowances which repay sales people for job related expenses, sales people undertake needed and desirable selling efforts, and fringe benefit pension and life insurance, provide job security and satisfaction.

\section{SUPERVISING SALES PEOPLE.}

Many companies help their sales people in identifying customers target and selling call norms, companies may specify how much time their sales force should spend prospecting for new account.

Companies may also direct sales people on how to use their time efficiently. One tool is the annual call in which months and which activities to carryout marketing research. Another tools is time and duty analysis in addition to time spent selling, the sales person time traveling administrative chores.

\section{EVALUATING SALES PEOPLE.}

This process requires good feedback means getting regular information about salesmen to evaluate their performances.

Management get information about it sales people in several ways. The most importance sales is sales report including weekly or monthly works plans sales person also write up their completed activities on cell report for which they are perfectly or wholly repaid.

Additional information comes from personal observation, customer's survey and talks with other sales people.

The sales manager might begin with a quantitative evaluation looking at a sales person's knowledge of the company product, competitors, territory and ask personal trait manner, appearance, speech and temperate can be rated. The sales manager can also review any problem in motivation or compliances.

Each company must decide what could be most useful to know, it should communicate these critical to salesman sot he they understand how their performance is evaluated and can make effort to improve it. Using sales force report and other information management can also conduct a more formal evaluation. 


\subsection{SELLING STYLE AND SALES PERFORMANCE PROCESS.}

This involves the various processes a sales man has to go through before actualizing the sales of his goods. Though, in actual practice the number of stages a sales person passes through in selling his products depends on the nature of the product and the selling situation that the salesperson is being confronted with.

In the sales of consumer goods that frequently purchased the sales person may not have to go through the whole process. In the case of manufacturing firm $\mathrm{s}$ and high technology products, the sales person may have to go through the whole processes as the buyers of such product are prepared to spend considerable time in purchasing such product (Nebo, 2006:15).

So many marketing authority has come with many different versions of selling style and sales performance process but for the purpose of this project we shall use Busch and Houston (1985) version.

This stages involves.

Prospecting

Pre-approach.

Approach

Handle of objectives

Closing sales.

Following up/after sales services.

Approach

Presentation

Handling objective

The close up

The follow up

\subsection{MANUFACTURING FIRM}

Manufacturing firm s are those purchased for further processing or for sue in conducting a business. Thus, the detention between a customer product and an manufacturing firm is based on the purpose for which product is bought.

Particular product might be a consumer or an manufacturing firm , that are classified according to the uses of the product and how they enter into the production process as against the classification of consumer products, which is on the basis of buying habits. The three groups of manufacturing firm and services include material and parts, capital items and supplies and services.

\section{RAW MATERIALS AND PARTS}

The raw materials consist of agricultural produce and goods usually found in their natural conditions which can be converted into different form as they move through the production process and also they are traceable and also in the manufacturers and product. Example of raw materials from agricultural product include cocoa, palm oil, wheat, livestock, logs, fruits, vegetables, crop natural product include fish, crude, petroleum, iron, cement, wires and parts.

Most manufacturer material and parts are sold directly to industrial used, prices and services are the major marketing factor, branding and advertising tend to be uses important.

Capital item are those capital goods sold as a whole for further production or use in business operations. It consists of equipment and installations. Equipments are those removable item which are used to facilitate production operations but do not form part of the finishes product.

Accessory equipment includes portable factory equipment includes portable factory equipment and tools (hand tools, forks, lift trucks) and office equipment counter desk calculator etc. they have a shorter life span than installations but longer life span than operating supplies and simple aid in the production process.

The final group of business products is supplies and services supplies include operation supplies. Operation supplies are low price convenience item which facilitates the manufacturers operation but do not become part of the end product (fuel wrapping materials, cleaning materials).

\section{REPAIRS AMD MAINTENANCE ITEMS}

This refers to variety of repair parts for repairing both plant and lubrication oil electrical parts plumbing material paints etc. 
Supplies are the convenience product of the industrial field because they are usually purchase with a minimum of effort for compares business services includes maintenance and repair services (window clearing, computer repair and business advertising such services are usually supplied under contract. 


\section{References}

[1]. Okorie Awa H. (2002) Modern Marketing theory, Enugu Ceckay Business Center

[2]. Okorie Festus, E.O (2004) Leeway to skillful selling Tony, Ben publishers, Owerri.

[3]. Onuoha, Kelechi via Amaechi A. E. (2005) Marketing Ideals and Dynamic Owerri Versatile publishers

[4]. Nebo Okwudili G. (2006) Sales management strategic and systematic approach, Owerri, Ugooma printing press \& co.

\section{Research Design And Methodology}

Research methodology is a blue point specially which approach will be used for the gathering and analyzing of the data. This specifically deals with the research source of data and types of data relevant to this research work the approach adopted to test analysis and interpret data. Since the study is concerned with the impact of selling style and sales performance on the manufacturing firm s. The researcher shall limit the study to cover only Port Harcourt using First Aluminum Company as a case study.

\subsection{INTRODUCTION}

Since the study is concerned with the impact of Selling style and sales performance on the Manufacturing firm $\mathrm{s}$. The questionnaires were designed to primary find out how impact and efficient management of selling style and sales performance had helped to increase customer's patronage in manufacturing firm s through impact interpersonal communication.

\subsection{RESEARCH DESIGN:}

The research design adopted for this research work is survey method, it is survey because it involves gathering of data through questionnaires administration. The questionnaires were designed to primarily find out how impact and efficient management of selling style and sales performance had helped to increase customer patronage in manufacturing firm s through impact interpersonal communication. The functions of the research design is to ensure that required data are collected accurately and economically (Anozie E. E. \& 2004:13)

\subsection{SOURCE AND METHOD OF DATA COLLECTION:}

The Data for the work were collected from two different source the primary and the secondary source data to ensure the collection of relevant adequate and reliable information that help in appreciation the problem at hand.

PRIMARY SOURCE: This were collected through administration of question and interviews in a bid to ensure that respondent feel very free as concerning their answer to the question much care was taking in the designing of the questionnaires, this was realize by the facts that respondents had option to disclose their action and in some case the respondent were expected to make suggestion where necessary.

The staff of first Aluminum in Port Harcourt were the respondent to the questionnaires.

SECONDARY SOURCE: This is the major data collection involve in the study, under this source information about the subject matter was gotten from professional funerals text books, magazine businesses, week line, newspaper records from the firm bulletin and pamphlets from the organizations and other related text from library.

\subsection{POPULATION AND SAMPLING SIZE:}

The population of the study consist of staff of first aluminum company at its headquarters office in Transamadi Port Harcourt. This organization has a staff population of 200 staffs in its headquarters office.

The choice of the corporate headquarter is because the topic of study is a corporate management issue which only the top management staff can provide the needed information below is the distribution table.

\begin{tabular}{|l|l|l|l|l|}
\hline Department & Top mgt level & Middle mgt level & Lower mgt level & Total \\
\hline Product dept & 10 & 5 & 5 & 20 \\
\hline Audit & 30 & 20 & 10 & 60 \\
\hline Marketing & 30 & 20 & 20 & 70 \\
\hline Purchasing & 20 & 20 & 10 & 50 \\
\hline Total & 90 & 65 & 45 & 200 \\
\hline
\end{tabular}

Due to the nature of topic on study, not all the population of this organization will be interviewed only personnel with sufficient knowledge on the research topic, hence the marketing department becomes the unit of analysis, there are seventy (70) marketing staff (Sample size). 
The sample size of 70 being the staff strength of marketing department at its corporate headquarters was taken from the total population of 200 this is because the topic on study is a marketing topic as such only marketing can provide relevant information.

\subsection{SAMPLING TECHNIQUE.}

The researcher will make use of judgmental sampling because only marketing department is going to be used for the study as they stand the chance of giving the right information.

\subsection{VALIDITY AND RELIABILITY OF MEASURING INSTRUMENT:}

The reliability which is the degree of stability consistence of the research instrument and validity which refers to the degree with which a research instrument measures what is designs to measure as well as the population is intended for.

Here the researcher consequently decided to create questionnaires that will get best results. Almighty all measuring instrument contains some level of errors no matter how precise and careful the efforts at observation. As a result, efforts should be directed of validity and reliability. Aylott (2001)

Validation is a proof that something is true for official acceptance. To ensure the validation of the research instrument of this study, the research instrument of this study, the research presented the research instrument to an expert for critical examination as regards to what intends to ascertain.

\subsection{METHOD OF DATA ANALYSIS.}

In analyzing the data collected researcher makes use of simple percentages and frequency distribution table.

The percentage was used to analyze all relevant questions in the question through the aid of tables.

It is mathematically represented thus:

$\% \mathrm{FN}=100 / 1$

The formular is written thus $\underline{\mathrm{F}}=100$

$\mathrm{N}-\mathrm{I}$

Where

$\mathrm{F} \quad=\quad$ Frequency of respondents to a particular question

$\mathrm{N}=$ Total number of respondent to a particular question

$\%=$ Percentage

IV. Presentation And Analysis Data.

Data analysis and presentation are the core of any meaningful research work, the degree of application of the research work references to the significance of the study depends on the careful analysis collected for the study.

\subsection{INTRODUCTION.}

In this chapter four (4) researcher will concentrate on presentation of information of data collected in this research exercise also the analysis.

\subsection{PRESENTATION OF DATA.}

As stated in chapter Three (3) on the source or method of data analysis that oral interview were held personal discussion were also held and seventy questionnaires were administered and distributed to the marketing department of First Aluminum Company Plc Port Harcourt.

Out of Seventy questionnaires distributed only sixty five (65) were answered and five (5) were not returned by the respondents.

\subsection{ANALYSIS OF DATA}

\section{QUESTION ONE}

Does your organization apply selling style and sales performance as a promotional tool?

\section{TABLE 4.3}

\begin{tabular}{|l|l|l|}
\hline RESPONSE & NUMBER & $\%$ OF RESPONSES \\
\hline Yes & 60 & $92 \%$ \\
\hline No & 5 & $8 \%$ \\
\hline Total & 47 & $100 \%$ \\
\hline
\end{tabular}

Source: Field survey, 2010

From the table above, 60 or $92 \%$ of the respondents said Yes, while 5 or $8 \%$ of the respondent said No. the implication of the above analysis is that majority of the staff of the organization are of the opinion that the organization applies personal selling. 
Question 2

If your answer above is yes, how do you appraise your company's selling style and sales performance programme.

Table 4.3.2 Appraisal of personal selling

\begin{tabular}{|l|l|l|}
\hline RESPONSE & NUMBER & $\%$ OF RESPONSES \\
\hline Very impact ive & 10 & $15 \%$ \\
\hline Impact ive & 15 & $23 \%$ \\
\hline Not impact ive & 40 & $62 \%$ \\
\hline Total & 65 & $100 \%$ \\
\hline
\end{tabular}

Source: Field survey, 2010

From the table above, 10 or $15 \%$ of the respondent said very impact ive, 15 or $23 \%$ of the respondent said impact while 40 or $62 \%$ of the respondent said Not impact ive.

The implication of the above analysis is that majority of the staff of the organization are of the opinion that selling style and sales performance is not impact ive.

Question three

If your answer above is not impact state the reasons for its inimpact iveness?

Table 4.3.3. Selling style and sales performance inimpact iveness

\begin{tabular}{|l|l|l|}
\hline Responses & Number & $\%$ of response \\
\hline Inadequate prospecting & 60 & $92 \%$ \\
\hline Poor timing & 40 & $62 \%$ \\
\hline Wrong approach & 50 & $77 \%$ \\
\hline Unattractive sales present- & 45 & $69 \%$ \\
\hline Cumulative & 55 & $85 \%$ \\
\hline
\end{tabular}

Source: Field survey, 2010

From the table above 60 or $90 \%$ respondents indicated inadequate prospecting, 40 or $62 \%$ respondent indicated poor timing f55 or $85 \%$ respondents indicated wrong approach 50 or $77 \%$ respondents indicated poor handling of objections 45 or $69 \%$ respondents indicated unattractive sales presentation.

On the aggregate 55 respondents or $85 \%$ of the respondents indicated all the options as reasons for the inimpact iveness of selling style and sales performance programme.

The implication is that inadequate prospecting in poor timing wrong approach poor handling of objections unattractive sales presentation are course for the inimpact iveness of selling style and sales performance programmes.

Question 4

Does your organization encounter any problem in carrying out selling style and sales performance programmes

Table 4.3.4 Problems of personal selling

\begin{tabular}{|l|l|l|}
\hline RESPONSE & NUMBER & $\%$ OF RESPONSES \\
\hline Yes & 45 & $69 \%$ \\
\hline No & 20 & $31 \%$ \\
\hline Total & 65 & $100 \%$ \\
\hline
\end{tabular}

Source: Field survey, 2010

From the table above, 45 or $69 \%$ the respondents aid yes, 20 or $31 \%$ said No. the implication of the above analysis is that majority of the staff are of the opinion that the organization encounter some problems in carrying out selling style and sales performance programme.

Question 5

If your answer above is YES identify the problems?

Table 4.3.5 Problems of personal selling

\begin{tabular}{|l|l|l|}
\hline RESPONSE & NUMBER & $\%$ OF RESPONSES \\
\hline Consumer perception & 55 & $85 \%$ \\
\hline Huge cost & 60 & $92 \%$ \\
\hline Developing magnetic & & \\
\hline Sales personality & 45 & $69 \%$ \\
\hline Inappropriate structure of sales force & 40 & $62 \%$ \\
\hline Cumulative response & 50 & $77 \%$ \\
\hline
\end{tabular}

Source: Field survey, 2010 
From the table above 55 or $85 \%$ respondents said consumer perception 60 or $92 \%$ respondents said huge cost 45 or $69 \%$ respondents said development magnetic sales personality 40 or $62 \%$ said inappropriate structure of sales force.

On the aggregate 55 or $77 \%$ of the respondents indicated all the option as problems encouraged in carrying out selling style and sales performance programme. The implication is that the above various are the problems encountered in carrying out personal program .

Question 6

Is there any relationship between impact selling style and sales performance programme and increase in companies market share?

Table 4.3.6 Selling style and sales performance and increases marketing share

\begin{tabular}{|l|l|l|}
\hline RESPONSE & NUMBER & $\%$ OF RESPONSES \\
\hline Yes & 60 & $92 \%$ \\
\hline No & 5 & $8 \%$ \\
\hline Total & 65 & $100 \%$ \\
\hline
\end{tabular}

Source: Field survey, 2010

From the implication of the above analysis, is that staff of the organization are of the opinion that there is relationship between selling style and sales performance and increase market share.

Question 7

If your above answer is yes, state how impact selling style and sales performance programme can be used to achieve increase in the market shares?

Table 4.3.7

\begin{tabular}{|l|l|l|}
\hline RESPONSE & NUMBER & $\%$ OF RESPONSES \\
\hline Prospecting & 50 & $77 \%$ \\
\hline Pre - approach & 45 & $69 \%$ \\
\hline Approach & 55 & \\
\hline Presentation & 40 & $62 \%$ \\
\hline Handling objective & 60 & $92 \%$ \\
\hline Closing sales & 40 & $62 \%$ \\
\hline Following up & 25 & $38 \%$ \\
\hline Cumulative responses & 45 & $69 \%$ \\
\hline
\end{tabular}

Source: Field survey, 2010

From the above table 50 or $77 \%$ respondents said prospecting 45 or $69 \%$ respondents indicated preapproach, 55 or $85 \%$ of respondents indicated approach, 40 or $62 \%$ respondent indicated presentation, 60 or $92 \%$ respondents indicated handling objective, 40 or $62 \%$ respondent indicated closing sales, 25 or $38 \%$ respondents indicated follow up.

On the aggregate 45 or $69 \mathrm{~T} \%$ of the respondent indicated all the option as how impact selling style and sales performance can be used to achieve increase in market share.

The implication is that the staff variables are how impact selling style and sales performance programme can used to achieve increases in market share.

Question 8

Do you think impact selling style and sales performance programme can being increases in marketing share of your organization?

Table 4.3.8 Impact selling style and sales performance and increases in marketing share

\begin{tabular}{|l|l|l|}
\hline RESPONSE & NUMBER & $\%$ OF RESPONSES \\
\hline Yes & 60 & $92 \%$ \\
\hline No & 5 & $8 \%$ \\
\hline Total & 65 & $100 \%$ \\
\hline
\end{tabular}

Source: Field survey, 2010

From the table above 60 or $92 \%$ said Yes while 5 or $8 \%$ said No the implication of the above analysis is that majority of the staff are of the opinion that impact selling style and sales performance programme can bring increased market share.

Question 9

If your answer above is Yes how can impact selling style and sales performance bring about increases sales volume. 
Table 4.3.9 Selling style and sales performance and increase sales volume

\begin{tabular}{|l|l|l|}
\hline RESPONSE & NUMBER & $\%$ OF RESPONSES \\
\hline Brand switching & 65 & $100 \%$ \\
\hline Brand loyalty & 45 & $69 \%$ \\
\hline Repeat purchase & 40 & $62 \%$ \\
\hline Cumulative response & 50 & $78 \%$ \\
\hline
\end{tabular}

Source, Field survey, 2010

From the above table 65 or $100 \%$ respondents indicated brand switching, 45 or $69 \%$ respondents indicate brand loyalty while 40 or $62 \%$ respondent indicated repeat purchase.

On the aggregate 50 or $78 \%$ respondent indicate all te option as how impact selling style and sales performance can being about increase sales volume.

The implication is that brand switching, brand loyalty and repeat purchase and ways impact selling style and sales performance program can being increase in sales volume.

Question 10

Do you think that impact selling style and sales performance programme can help to achieve better customer services?

Table 4.3.10 Impact selling style and sales performance and better customer services

\begin{tabular}{|l|l|l|}
\hline RESPONSE & NUMBER & $\%$ OF RESPONSES \\
\hline Yes & 55 & $85 \%$ \\
\hline No & 10 & $15 \%$ \\
\hline Total & 65 & $100 \%$ \\
\hline
\end{tabular}

Source: Field survey, 2010

From the table above, 55 or $85 \%$ respondent indicated Yes, while 10 or $15 \%$ indicated No. The implication of the above analysis is that majority of the staff of the organization are of the opinion that impact selling style and sales performance programme can help to achieve a better customer services.

\subsection{INTERPRETATION OF RESULTS}

To interpret results listed in chapter one the researcher used frequently tables and percentages to analysis in chapter three (3) and was tested at $5 \%$ level of significance.

Therefore, there is no significant relationship between selling style and sales performance and increase in sales volume of manufacturing firm s. Also, there is significant relationship between selling style and sales performance and increase in sales volume of manufacturing firm $\mathrm{s}$.

\subsection{INTRODUCTION}

\section{Summary, Conclusion \& Recommendation.}

In the process of carrying out this research work, the researcher examined the analysis of the impact of selling style and sales performance in the manufacturing firm and the emphasis was on First Aluminum company Port Harcourt

The analysis of this study shows that the company makes use of selling style and sales performance as the company makes use of selling style and sales performance as the promotional tool and there is a relationship between impact selling style and sales performance and increase in the company's market share.

\subsection{SUMMARY OF FINDINGS.}

Finding were made from the questionnaires distributed to the staff of marketing department of First Aluminum company, the questionnaires was constructed in line with the purpose of the study and the findings will benefits both the industrial supplier and users of the company.

It shows Selling style and sales performance helps to achieve the company's marketing objective and improve their customer services.

They analysis of the study also revealed some defeats in the current selling style and sales performance programmes of the company. Despite the high cost of selling style and sales performance the benefit still justifies the cost

Finally, the analysis however reveals that their salesmen were adequately trained and are well remunerated for their exercise.

\subsection{CONCLUSION}

Selling style and sales performance has been tested and proved to be impact but very costly for a firm to adopt. Not notwithstanding it still serves as the best option for manufacturing firm marketing.

DOI: $10.9790 / 487 X-18080386100 \quad$ www.iosrjournals.org $99 \mid$ Page


There is an inseparable relationship between impact selling style and sales performance of sales force and increase in sales volume of manufacturing firm. It helps to achieve the company marketing goals and brings about goods customer services. Industrialist has not really seen the importance of selling style and sales performance due to the high cost involved, through its benefits still justifies the cost. Selling style and sales performance is the resort to increase sales volume.

\subsection{RECOMMENDATION.}

The manufacturing firm $s$ have not been like that of consumer product. But firm should try to adopt selling style and sales performance to market their manufacturing firm .

They should first of all: -

Carry out feasibility study on the cost and benefit analysis of the exercise.

Organize work shop for salesmen on the need to actualize their benefit and objectives of the organization.

Should educate their target by way of either exhibition and through the medium of personals selling on the benefit of using and patronizing them.

Employ able body youths that are dynamic and trained for the exercise.

\section{Bibliography}

[1]. EGU, A.O (2009,8-1) Industrial marketing divine publishers ABA.

[2]. NEBO OKWUDILI G. (2006) Sales management strategies systematic approach Owerri, Ugooma printing press

[3]. NEBO OKWUDILI G. (2004) Marketing Contemporary comprehensive approach Owerri rock business concerns

[4]. OKORIE FESTUS E. (2004) Leeway to Skillful Selling, Owerri Tony Ben

[5]. OKORIE AWA H. (2002) Strategic Marketing Promotion Mix Enugu, Ceckay business centre

[6]. OKORIE AWA H. (2002) Modern Marketing Theory Enugu, Ceckay business centre

[7]. ONUOHA KELECHI J. Via AMAECHI A.E. (1995) Marketing Ideals and Dynamic Owerri Versatile publisher 